Hans Kirkegaard-Nielsen MD PhD, Peter Lindholm MD, Henrik Stougaard Petersen MD, Inge Krogh Severinsen MD

\title{
Antagonism of block in obese patients block in obese patients
}

Purpose: To investigate the relationship between total body weight (TBW) or body mass index (BMI) and atracurium reversal time.

Methods: The study population comprised 25 patients with TBW $<80 \mathrm{~kg}$ and 25 patients with TBW $\geq 80 \mathrm{~kg}$ anaesthetised with midazolam, thiopentone, fentanyl, nitrous oxide and halothane. Neuromuscular block was induced with $0.5 \mathrm{mg} \cdot \mathrm{kg}^{-1}$ atracurium and maintained with doses of $0.15 \mathrm{mg} \cdot \mathrm{kg}^{-1}$. Neuromuscular transmission was recorded using train-of-four (TOF) nerve stimulation and mechanomyography. Neostigmine, $0.07 \mathrm{mg} \cdot \mathrm{kg}^{-1}$, was administered when the first twitch in TOF had recovered to $10 \%$ of control. Reversal time was defined as: time from administration of neostigmine until TOF ratio recovered to 0.70 .

Results: There was no difference in reversal time between patients with TBW $<80 \mathrm{~kg}(7.2 \pm 2.6$ min, mean $\pm \mathrm{SD})$, and patients with $\mathrm{TBW} \geq 80 \mathrm{~kg}(6.9 \pm 3.6 \mathrm{~min})$. When patients were grouped according to $\mathrm{BMI}$ there was no difference in reversal time between groups with low BMl $(6.9 \pm 2.6 \mathrm{~min})$ or high $\mathrm{BMI}(7.1 \pm 3.6 \mathrm{~min})$. There was, furthermore, no difference in reversal time between the 15 patients in the study population with the smallest TBW or BMI and the 15 patients with the greatest TBW or BMI. There was no correlation between TBW or $\mathrm{BMI}$ and reversal time.

Conclusion: When atracurium-induced neuromuscular block is antagonised with $0.07 \mathrm{mg} \mathrm{kg}^{-1}$ neostigmine, TBW or BMI have no influence on reversal time.

Objectif : Examiner la relation entre le poids corporel total ou l'index de masse corporelle (IMC) et le temps nécessaire pour inverser l'effet de l'atracurium.

Méthodes : La population étudiée se composait de 25 patients avec poids $<80 \mathrm{~kg}$ et 25 patients avec poids $>80 \mathrm{~kg}$, tous anesthésiés avec midazolam, thiopental, fentanyl, $\mathrm{N}_{2} \mathrm{O}$ et halothane. Le bloc neuro-musculaire était obtenu avec de l'atracurium à raison de $0,5 \mathrm{mg} \cdot \mathrm{kg}^{-}$et maintenu avec des doses de $0,15 \mathrm{mg} \cdot \mathrm{kg}^{-1}$. La transmission neuro-musculaire était évaluée au moyen de la stimulation nerveuse de type train de quatre (TOF) et de la mécano-myographie. La néostigmine était administrée à raison de $0,07 \mathrm{mg} \cdot \mathrm{kg}^{-1}$ lorsque la première réponse au train de quatre avait récupéré à $10 \%$ de la valeur contrôle. Le temps nécessaire à inverser l'effet de l'atracurium était calculé à partir du début de l'administration de la néostigmine jusqu'à ce que la valeur du TOF soit de 0,7.

Résultats : II n'y a pas eu de différence dans le temps nécessaire pour inverser l'effet de l'atracurium entre les patients du groupe de $<80 \mathrm{~kg} 7,2 \pm 2,6 \mathrm{~min}$., moyenne $\pm E T$ ) et ceux du groupe $>80 \mathrm{~kg}(6,9 \pm 3,6 \mathrm{~min}$.). Lorsque les patients sont regroupés selon leur IMC, il n'y a pas de différence entre ceux avec IMC bas $(6,9 \pm 2,6$ min.) et ceux avec IMC élevé (7,I $\pm 3,6 \mathrm{~min}$.). En outre, il n'y avait pas de différence dans le temps d'inversion du bloc entre les 15 plus petits patients selon le poids ou l'index et les 15 plus gros. II n'y avait pas de corrélation entre le temps d'inversion du bloc et le poids ou l'index de masse corporelle.

Conclusion : Lorsque le bloc neuro-musculaire induit par l'atracurium est antagonisé par la néostigmine 0,07 $\mathrm{mg} \cdot \mathrm{kg}^{-1}$, le poids ou l'IMC n'ont pas d'influence sur le temps nécessaire à l'inversion de l'effet de l'atracurium.

From the Department of Anesthesia and Intensive Care, Odense University Hospital, DK-5000 Odense C, Denmark.

Address correspondence to: $\mathrm{H}$. Kirkegaard-Nielsen MD, UCSF, Department of Anesthesia, 521 Parnassus Avenue, San Francisco, CA 94143-0648.

Accepted for publication October 25, 1997. 
I $\mathrm{N}$ the obese patient atracurium has a prolonged duration of action when dosed on a $\mathrm{mg} \cdot \mathrm{kg}^{-1}$ total body weight (TBW) formula. ${ }^{1}$ It is believed that this prolonged duration of action is due to a relative overdose of the blocking agent. ${ }^{1}$ It has also been demonstrated that atracurium has a slightly cumulative effect. ${ }^{2}$ The anticholinesterase neostigmine ${ }^{3,4}$ has a low fat solubility, and when dosed on a $\mathrm{mg} \cdot \mathrm{kg}^{-1} \mathrm{TBW}$ formula, a large dose relative to lean body mass is given to the obese patient. Our goal in the present study is to determine if atracurium reversal time is influenced by TBW or body mass index (BMI) when atracurium and neostigmine are dosed on a mg. $\mathrm{kg}^{-1} \mathrm{TBW}$ formula.

\section{Methods}

The protocol was approved by the local Ethics Committee, and written informed consent was obtained from each patient. The study population comprised 50 ASA physical status 1 or 2 women, 25 with a TBW $<80 \mathrm{~kg}$ (group I) and 25 with a TBW $\geq 80 \mathrm{~kg}$ (Group II).

Total body weight was measured, and body mass index (BMI) was calculated as TBW in $\mathrm{kg}$ divided by the squared height in metres. ${ }^{5}$ The patients were also grouped according to $\mathrm{BMI}$ in a high $\mathrm{BMI}$ and a low BMI group. In order to get more distinct groups in respect to TBW and BMI, groups consisting of the 15 patients with the lowest TBW/BMI and the 15 patients with the highest TBW/BMI were formed.

Patients were premedicated with $50 \mathrm{mg}$ dixyrazine (a phenothiazine derivative) po. Anaesthesia was induced with $0.04 \mathrm{mg} \cdot \mathrm{kg}^{-1}$ midazolam and $3 \mu \mathrm{g} \cdot \mathrm{kg}^{-1}$ fentanyl followed by $5 \mathrm{mg} \cdot \mathrm{kg}^{-1}$ thiopentone and maintained with halothane $0.5 \%$ end-tidal concentration (Normac ${ }^{\circledR}$, Datex, Helsinki, Finland), 65 to $70 \%$ nitrous oxide in oxygen, and supplementary doses of $100 \mu \mathrm{g}$ fentanyl, 50 $\mathrm{mg}$ thiopentone, or $1 \mathrm{mg}$ midazolam as required. Both halothane and nitrous oxide concentrations were kept constant throughout the study. Temperatures were monitored centrally and peripherally. (TR9 $®$, Ellab, Copenhagen, Denmark).

The ulnar nerve was stimulated supramaximally at the wrist (Myotest DBS ${ }^{\circledR}$, Biometer, Odense, Denmark). When the neuromuscular response to train-of-four (TOF) stimulation had stabilised, $\mathrm{Tl}$, the magnitude of the first twitch in TOF was recorded as the control twitch ( $\mathrm{Tl}$ control). The evoked contractions in the adductor pollicis muscle were recorded using a forcedisplacement transducer with a pre-load of 200-300 $\mathrm{g}$ (Myograph $2000 \circledast$, Biometer, Odense, Denmark).

Neuromuscular block was induced with a bolus dose of $0.5 \mathrm{mg} \cdot \mathrm{kg}^{-1}$ atracurium and maintained with supplementary doses of $0.15 \mathrm{mg} \cdot \mathrm{kg}^{-1}$. After the end of surgery and when $\mathrm{Tl}$ had recovered to $10 \%$, the neu- romuscular block was antagonised by $0.07 \mathrm{mg} \cdot \mathrm{kg}^{-1}$ neostigmine preceded by $0.028 \mathrm{mg} \cdot \mathrm{kg}^{-1}$ atropine. The neostigmine dose was based on clinical recommendations. ${ }^{6}$ Reversal time was defined as: time from administration of neostigmine until the TOF ratio had recovered to 0.70 .

\section{Statistics}

Students $t$ test for unpaired data, F-test (variance ratio test) and linear regression analyses were used, $P<0.05$ was considered as statistically significant.

\section{Results}

Age and TBW of the patients in group I was $40 \pm 6 \mathrm{yr}$ mean $\pm S D$ and $62 \pm 9 \mathrm{~kg}$ respectively, and in group II, $45 \pm 8 \mathrm{yr}$ and $90 \pm 10 \mathrm{~kg}$, respectively. Body mass index was $22.5 \pm 2.5 \mathrm{~kg} \cdot \mathrm{m}^{-2}$ in the 25 patients with the lowest BMI (low BMI group) and $32.3 \pm 4.7 \mathrm{~kg} \cdot \mathrm{m}^{-2}$ in the 25 patients with the highest BMI (high BMI group).

There was no difference in reversal time between group I and II, $7.2 \pm 2.6$ and $6.9 \pm 3.6 \mathrm{~min}$ respectively. When the patients were grouped according to BMI there was no difference in reversal time between the low and the high $\mathrm{BMI}$ group, $6.9 \pm 2.6$ and $7.1 \pm 3.6 \mathrm{~min}$ respectively.

When the 15 patients with the lowest TBW/BMI were compared with the 15 patients with the greatest TBW/BMI, there was still no difference in reversal time, $P>0.05$, (Tables I and II).

There was no difference in reversal time variance between any of the groups. Linear regression showed no correlation between reversal time and TBW or between reversal time and BMI.

The temperature at the thenar eminence was $>32.0^{\circ} \mathrm{C}$ and the central temperature was $>36.0^{\circ} \mathrm{C}$ at all times.

TABLE I Reversal time in the 15 patients with the lowest total body weight (TBW) and in the 15 patients with the highest TBW

\begin{tabular}{llllllll}
\hline & \multicolumn{3}{c}{ Low TBW } & \multicolumn{3}{c}{ bigh TBW } \\
\hline & Mean & SD & (range) & mean & SD & (range) \\
TBW kg & 56.3 & 4.0 & $(46-61)$ & 95.6 & 9.5 & (88-119) \\
Reversal & & & & & & \\
$\quad$ time (min) & 8.3 & 2.6 & $(3.8-13.5)$ & 6.9 & 3.8 & $(1.8-13.5)$ \\
\hline
\end{tabular}

TABLE II Reversal time in the 15 patients with the lowest body mass index (BMI) and in the 15 patients with the highest BMI

\begin{tabular}{|c|c|c|c|c|c|c|}
\hline & \multicolumn{3}{|c|}{ low $B M I$} & \multicolumn{3}{|c|}{ high $B M I$} \\
\hline & Mean & SD & (range) & mean & SD & (range) \\
\hline $\mathrm{BMI} \mathrm{kg} \cdot \mathrm{m}^{-2}$ & 20.8 & 1.4 & $(18.6-22.8)$ & 34.4 & 4.8 & $(30.9-45.7)$ \\
\hline $\begin{array}{l}\text { Reversal } \\
\quad \text { time (min) }\end{array}$ & 7.9 & 2.7 & $(3.5-13.5)$ & 7.1 & 4.1 & $(1.8-15.2)$ \\
\hline
\end{tabular}




\section{Discussion}

The study demonstrates that neostigmine induced reversal time from atracurium block is unaffected by obesity.

It is known that neostigmine has a maximum "ceiling" effect. ${ }^{7}$ The exact maximum dose in humans is not known, but it is probably between 0.035 and $0.07 \mathrm{mg} \cdot \mathrm{kg}^{-1} .8,9$ All the patients in the present study received neostigmine $0.07 \mathrm{mg} \cdot \mathrm{kg}^{-1} \mathrm{TBW}$. Thus, every patient received a neostigmine dose that should result in the maximum effect. This may be one of the explanations why reversal time was independent of TBW and BMI.

A second factor that may influence reversal is the large atracurium dose relative to lean body mass given to the obese patient. As the $25-75 \%$ recovery time increases with increasing doses of atracurium ${ }^{2}$ reversal time may increase too. However, the neostigmine dose given to the obese patient is also large relative to lean body mass and may balance the effect of the large atracurium dose, resulting in a reversal time unaffected by body build.

There is also the possibility that the difference between the groups is too small to be detected. With a power of $75 \%$ and a significance level of $5 \%$ the study is capable of detecting a minimal difference of approximately $2.3 \mathrm{~min}$. However a difference in reversal time of $<2.5-3$ min seems clinical unimportant.

Body Mass index is the weight in $\mathrm{kg}$ divided by the squared height in metres. ${ }^{5}$ The BMI is thus better correlated with the percentage of fat in the human body than is total body weight. The patient population was, therefore, also grouped and compared according to BMI. However, similar results and conclusions were obtained whether TBW or BMI were used in the tests.

In conclusion, when an atracurium-induced neuromuscular block ( $\mathrm{T} 110 \%$ of $\mathrm{Tl}$ control) is antagonised by neostigmine $0.07 \mathrm{mg} \cdot \mathrm{kg}^{-1}$, reversal time is independent of body build (TBW and BMI).

\section{Acknowledgment}

The authors thank Dr. James Caldwell for his critical comments and suggestions.

\section{References}

1 Kirkegaard-Nielsen H, Helbo-Hansen HS, Lindholm P, Severinsen IK, Pedersen HS. Anthropometric variables as predictors for duration of action of atracurium-induced neuromuscular block. Anesth Analg 1996; 83: 1076-80.

2 Wright PMC, Hart P, Lau M, Sharma ML, Gruenke L, Fisher DM. Cumulative characteristics of atracurium and vecuronium. A simultaneous clinical and pharmacokinetic study. Anesthesiology 1994; 81: 59-68.
3 Williams NE, Calvey TN, Chan $K$. Clearance of neostigmine from the circulation during the antagonism of neuromuscular block. $\mathrm{Br}$ J Anaesth 1978; 50: 1065-7.

4 Cronnelly $R$, Stanski DR, Miller RD, Sheiner LB, Sobn $Y J$. Renal function and the pharmacokinetics of neostigmine in anesthetized man. Anesthesiology 1979; 51: 222-6.

5 Garrow JS, Webster J. Quetelet's index $\left(\mathrm{W} / \mathrm{H}^{2}\right)$ as a measure of fatness. Int J Obes 1985; 9: 147-53.

6 Bevan DR, Donati F, Kopman AF. Reversal of neuromuscular blockade. Anesthesiology 1992; 77: 785-805.

7 Bartkowski RR. Incomplete reversal of pancuronium neuromuscular blockade by neostigmine, pyridostigmine, and edrophonium. Anesth Analg 1987; 66: 594-8.

8 Magorian TT, Lynam DP, Caldwell JE, Miller RD. Can early administration of neostigmine, in single or repeated doses, alter the course of neuromuscular recovery from a vecuronium-induced neuromuscular blockade? Anesthesiology 1990; 73: 410-4.

9 Kirkegaard-Nielsen $H$, Helbo-Hansen HS, Lindholm P, Severinsen $I K$, Bülow $K$. Time to peak effect of neostigmine at antagonism of atracurium- or vecuroniuminduced neuromuscular block. J Clin Anesth 1995; 7: 635-9. 